\begin{tabular}{|l|c|}
\hline & $\begin{array}{c}\text { EFFECT OF ELECTROPULSES ON THE MACHINABILITY OF A C45E } \\
\text { STEEL }\end{array}$ \\
Ingeniería e Industria & $\begin{array}{c}\text { AGRONOMY } \\
\text { RESEARCH ARTICLE }\end{array}$ \\
\hline
\end{tabular}

\title{
EFFECT OF ELECTROPULSES ON THE MACHINABILITY OF A C45E STEEL
}

\author{
Carlos A. Montilla-Montaña ${ }^{1}$, Valentina Kallewaard-Echeverri², Hernán A. González-Rojas ${ }^{3}$ \\ 1 Universidad Tecnológica de Pereira, Escuela de Tecnología Mecánica, professor, postal address: carrera 27 \#10-02 Barrio \\ Álamos, Pereira, Colombia, teléfono: 3137124 extensión 7605, cmontilla@utp.edu.co \\ 2Universidad Tecnológica de Pereira, Facultad de Ingeniería Mecánica, professor, postal address: carrera 27 \#10-02 Barrio \\ Álamos, Pereira, Colombia, teléfono: 3137124 extensión 7614. \\ 3Departament d'Enginyeria Mecànica (EPSEVG), Grupo GAECE, Universitat Politècnica de Catalunya, Av. \\ de Víctor Balaguer Vilanova i la Geltrù. 08800, Barcelona, España. \\ Received: 8/May/2018 - Reviewing: 11/May/2018 --Accepted: 26/Sep/2018 -- DOl: http://dx.doi.org/10.6036/8829 \\ TO CITE THIS ARTICLE: \\ MONTILLA-MONTAÑA, Carlos Alberto, KALLEWAARD-ECHEVERRI, Valentina, GONZALEZ-ROJAS, Hernan A. et al. EFFECT \\ OF ELECTROPULSES ON THE MACHINABILITY OF A C45E STEEL . DYNA, January 2019, vol. 94, no. 1, p.94-99. DOI: \\ http://dx.doi.org/10.6036/8829
}

\section{EFECTO DE LOS ELECTROPULSOS SOBRE LA MAQUINABILIDAD DE UN ACERO C45E}

\section{ABSTRACT:}

This article compares the machinability of a C45E (AISI/SAE 1045) steel type under two different manufacturing processes: conventional machining and pulsed current assisted machining. The testing procedure consisted on the dry turning, using a coated carbide cutting tool (HM) and highspeed steel (HSS) cutting tools, under two different spindle speeds. In this study cutting tool life is evaluated in function of cutting speed for both machining conditions and both cutting tools. Results show variation on flank wear depending on the tool used and cutting speed, showing an increase in machinability when using the HM tool with the electropulse assisted turning at low cutting speed. Additionally, changes in chip type are found when assisting the process with electropulses. Statistically significant variations in chip dimensions and chip ratio are present, evidencing the differences in the phenomena affecting shear strain. Surface roughness, for its part, is improved when turning with the assistance of electropulses.

Keywords: electropulse, electroplastic effect, machinability, flank wear, chip ratio

\section{RESUMEN:}

En este artículo se compara la maquinabilidad de un acero C45E (AISI/SAE 1045) bajo dos procesos diferentes de fabricación, mecanizado asistido por pulsos de corriente y convencional. El ensayo consiste en un mecanizado en seco, realizado con herramientas de carburo metálico HM y herramientas de corte de acero rápido HSS, bajo dos velocidades de corte diferentes. En este estudio se evalúa la vida de la herramienta en función de la velocidad de corte, para los procesos mencionados y para las dos herramientas en estudio. Los resultados muestran variaciones en los desgastes de flanco, dependiendo de la herramienta utilizada y de la velocidad de corte, encontrándose un incremento de la maquinabilidad cuando se asiste con electropulsos el torneado con herramienta $\mathrm{HM}$ a una baja velocidad de corte. Adicionalmente se encuentran cambios en los tipos de viruta al asistir el proceso con electropulsos. Estadísticamente se presentan variaciones significativas en las dimensiones y en las relaciones de las virutas, evidencia de los cambios que sucedieron en los fenómenos de recalcado. Por su parte, la rugosidad superficial mejora al tornear con la asistencia de electropulsos.

Palabras clave: electropulso, efecto electroplástico, maquinabilidad, desgaste de flanco, relación de viruta

\section{1.- INTRODUCTION}

According to Brecher [1], hybrid manufacturing processes correspond to the combination of a conventional and an unconventional process, such as the pulse laser wire depositing and high-speed milling techniques developed by Ye et al. [2], or the hybrid-layered manufacturing process performed on a CNC machine by Sajan et al. [3]. Amongst the hybrid processes family, Electrically Assisted Forming (EAF) processes are novel techniques. In an EAF process an

Publicaciones DYNA SL - c) Mazarredo nº9 - 40 -- 48009-BILBAO (SPAIN)
Tel +34 $944237566-$ www.revistadyna.com - email: dyna@revistadyna.com




\begin{tabular}{|l|c|}
\hline & $\begin{array}{c}\text { EFFECT OF ELECTROPULSES ON THE MACHINABILITY OF A C45E } \\
\text { STEEL }\end{array}$ \\
\hline $\begin{array}{c}\text { Ingeniería e Industria } \\
\text { RESEARCH ARTICLE }\end{array}$ & $\begin{array}{c}\text { Carlos A. Montilla Montaña, Valentina Kallewaard Echeverri, Hernán A. } \\
\text { González Rojas }\end{array}$ \\
\hline
\end{tabular}

electrical current is circulated through a metal that is being formed. EAF processes are based in the so-called electroplastic effect, in which thermal and athermal effects improve the formability of a metallic material; a more detailed explanation is provided by Spitsyn and Troitskii [4], according to which, at the atomic level, the application of the pulsed current generates changes in resistivity in metallographic defects facilitating the mobility of dislocations and mechanical modification of the material.

Several authors describe the characteristics and advantages of EAF processes. Valoppi et al. [5], show that the application of electropulses in the forming of a Ti6Al4V alloy sheet increases its formability, improves geometric accuracy and reduces forming forces. Hameeb et al. [6] found out that the use of electropulses in the drilling process of C45E carbon steel and ENAW7075 aluminum improves the machinability of the material. A compilation of studies performed around the EAF manufacturing techniques, elaborated by Salandro et al. [7], shows the advantages this technique presents and augurs a swift transit into the industry given its potential benefits. Nevertheless, EAF technology is still in experimental phase.

The assisted turning process studied in this work consists in the combination of conventional turning of metals with an electropulse train of a known width and frequency. According to Sánchez et al. [8-10] the combined effect of plastic deformation and high-energy electropulsing treatment (EPT) reduces surface roughness, modifies surface hardness and reduces the power consumption necessary for the machining process. Those results were obtained turning 42CrMo4, C45E and C20 steels, using different spindle speeds, feeds and different conditions for the electropulses.

According to Groover [11], machinability can be assessed with regard to tool life, machining forces and power, surface finish and ease of chip removal. The investigation of new materials for the industry generates the necessity to study its machinability as is the case of: Zhang and Liu [12] who investigate the machinability on turning of Cr-Ni based stainless steel cladding formed by laser cladding process, Wang et al. [13] research a new methodology to perform face milling on 4 different superalloys and Geng et al. [14] investigate the influence of copper content in machinability and corrosion resistance of martensitic stainless steel. This helps with proper tool and cutting conditions selection, allowing for increases in production and reduction of manufacturing costs.

In this study, we focused on investigating the machinability of the material when the turning process is assisted by electropulsing. It is currently unknown if the pulsed current promotes tool wear or, on the contrary, if it increases its useful life, which is the fundamental reason behind the present study. To do that, an approximate test was applied to determine tool life on dry turning, with and without the assistance of high density pulsed current, and with HM and HSS tools under two spindle speeds. According to the guidelines of the standard ANSI/ASME B94.55M, and applying a direct and intermittent optical method, the tests were performed until the tool's flank wear $V_{B}$ reached a value of around $0,5 \mathrm{~mm}$, to later obtain mathematical models by regression. $V_{B}$ was also evaluated by indirect methods through the measurement of changes in surface roughness. Lastly changes in morphology and dimensions of the obtained chips were analyzed.

\section{2.- MATERIALS AND METHODOLOGY}

According to Siddhpura and Paurobally [15], the life of a cutting tool can be measured directly with an optical method or indirectly by the changes in surface roughness and vibrations. In this work an optical method is used to measure flank wear directly and the measurement of surface roughness of the machined pieces is used to determine it indirectly.

\section{1.- MATERIALS}

Commercial C45E steel rods, were the as-received material, which comes from previous cold-rolled process. The workpieces were prepared in the lathe machine to match the dimensions of $12,7 \mathrm{~mm}$ in diameter and $120 \mathrm{~mm}$ in length, useful length of $75 \mathrm{~mm}$. The material hardness is $108 \mathrm{HRB}$ and its chemical composition can be found on [16].

\section{2.- ELECTROPULSING ASSISTED TURNING PROCESS}

The oblique turning process was conducted in a lathe machine model TOZ, ZPS-R5. The specimens were placed between the chuck and the tailstock. Two kinds of cutting tools were used during the experiments: high speed steel HSS 


$\left.\begin{array}{|c|c|c|}\text { EFFECT OF ELECTROPULSES ON THE MACHINABILITY OF A C45E } \\ \text { InTEEL }\end{array}\right]$

and tungsten material HM (Hard Metal). The dimensions of the HSS cutting tool are 5/16" x 5/16" x $21 / 2$ " (7,94 mm x $7,94 \mathrm{~mm} \times 63,5 \mathrm{~mm}$ ), the clearance angle $\alpha$ is $8^{\circ}$, the rake angle $\gamma$ is $14^{\circ}$, the nose radius $R_{t}$ is $1,6 \mathrm{~mm}$, without chipbreaker, and the principal cutting edge angle $\phi$ is $40^{\circ}$. The hard metal HM cutting tool is classified with the following reference SNMG $120404 \mathrm{SH}$ NX2525, the clearance angle $\alpha$ is $3^{\circ}$, the nose radius $R_{t}$ is $0.4 \mathrm{~mm}$, with chipbreaker, and the principal cutting edge angle $\phi$ is $30^{\circ}$. The cutting parameters are shown in Table 1 .

\begin{tabular}{|c|c|c|c|c|c|c|c|c|c|}
\hline Condition & C1 & C2 & C3 & C4 & C5 & C6 & C7 & C8 \\
\hline Tool & HM & HM & HM & HM & HSS & HSS & HSS & HSS \\
\hline Spindle speed (RPM) & 1133 & 1133 & 573 & 573 & 914 & 914 & 573 & 573 \\
\hline Cutting speed (m/min) & \multicolumn{2}{|c|}{45} & \multicolumn{2}{|c|}{23} & \multicolumn{2}{|c|}{36} & \multicolumn{2}{|c|}{23} \\
\hline Feed (mm/rev) & 0,174 & 0,174 & 0,174 & 0,174 & 0,138 & 0,138 & 0,138 & 0,138 \\
\hline Electropulsing & Yes & No & Yes & No & Yes & No & Yes & No \\
\hline Depth of cut (mm) & 1 & 1 & 1 & 1 & 1 & 1 & 1 & 1 \\
\hline Rake angle Y (') & 3 & 3 & 3 & 3 & 14 & 14 & 14 & 14 \\
\hline $\begin{array}{c}\text { Principal cutting Edge } \\
\text { angle } \Phi\left(^{\circ}\right)\end{array}$ & 30 & 30 & 30 & 30 & 40 & 40 & 40 & 40 \\
\hline
\end{tabular}

Table 1. Test conditions and metal-cutting parameters

According to several works on flank wear, the variable that affects its behavior the most is the cutting speed Vc [11], [15], [17-18] which is why it has been selected as an independent variable. It has been decided to use the methodology proposed by Taylor [19] to study tool life, in which the experiment variables are fixed except for one, Vc, which varies in a predetermined range.

A problem that has been observed by authors on electopulsing assisted turning consists in that the formed chip can't be continuous, since it is connected to ground with the machine, with the consequent loss of the electroplastic effect on the piece; on the other hand, for the case of HM tool an electroerosion phenomenon is generated which damages the cutting area and makes the test fail. In order to select the range in which Vc varies, preliminary tests were performed, to determine feeds and cutting speeds for which a continuous chip was not produced (see Table 1).

Figure 1 shows the system to electrically assist the process. A pulse generator, controlled by MOSFET transistors, sends pulses with frequencies ranging from 100 to $400 \mathrm{~Hz}$, its duration varying from 50 to $200 \mu$ s and a maximum current intensity of $130 \mathrm{~A}$. The parameters of the current such as frequency and pulse duration were monitored by an oscilloscope. The electropulses are transmitted to the tool, through the material and, using metallographic clamps, the circuit of the generator is closed. Polymeric dies were developed to isolate the specimen and the cutting tool from the lathe machine. 


\begin{tabular}{|c|c|c|c|} 
EFFECT OF ELECTROPULSES ON THE MACHINABILITY OF A C45E \\
STEEL \\
Ingeniería e Industria \\
RESEARCH ARTICLE
\end{tabular}

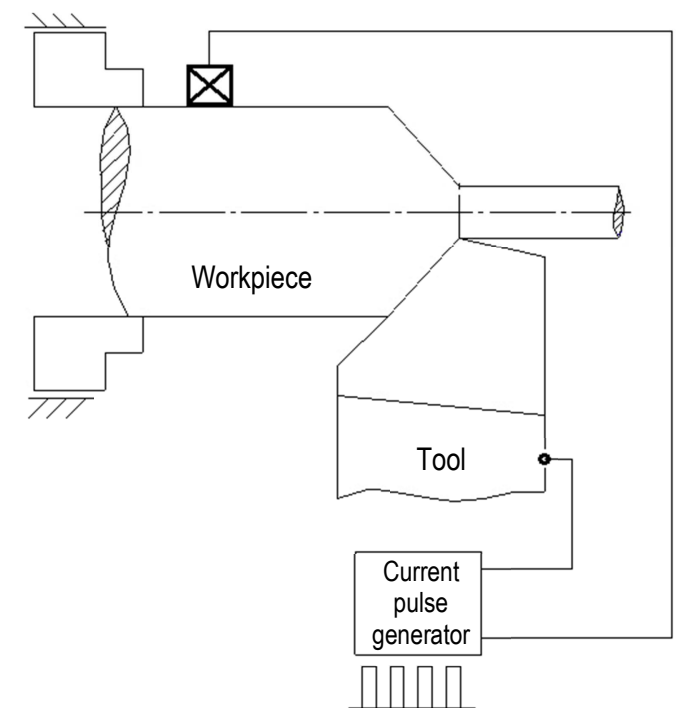

Fig. 1. Experimental schematic of the process

The electroplastic phenomenon manifests when an electrical current is circulated through a conductive material submitted to great plastic deformation. In a chip removal process the primary shear zone $\mathrm{A}_{\mathrm{c}}$ is the one with the greatest plastic deformation. If an electrical current is circulated through this zone, then the two conditions that promote the occurrence of the electroplastic phenomenon are present. This implies the necessity to know the current per area unit circulating through $\mathrm{A}_{\mathrm{c}}$ or current density $J$. To that end the primary shear zone $A_{c}$ is estimated, and the current provided by the generator is measured. Figure 2 shows a simplified schematic of an oblique turning process, the $A_{c}$ area is defined by the OABC plane and the angles and variables involved in the definition of the cutting geometry are: principal cutting edge angle $\phi$, shear angle $\varphi$, rake angle $\gamma$, feed $f$, depth of cut $d$, chip thickness $t_{c}$, uncut chip thickness $t_{o}$ and width of cut $W_{c}$. From Figure 2 the shear plane area $A_{c}$ is deduced as the length OA multiplied by the length OC, and considering the geometry of the oblique cut, as follow:

$$
A_{c}=\frac{f \cdot \sin \phi}{\sin \varphi} \cdot W_{c}
$$

The chip ratio $r_{c}$ is a characteristic geometric parameter of chip removal processes and for turning it is calculated as:

$r_{c}=\frac{f \cdot \sin \phi}{t_{c}}$

From the geometry of the orthogonal cut the known expression for the shear angle $\varphi$ is deduced:

$\tan \varphi=\frac{\cos \gamma}{r-\sin \gamma}$ 


\begin{tabular}{|c|c|c|}
\hline & $\begin{array}{l}\text { EFFECT OF ELECTROPULSES ON THE MACHINABILITY OF A C45E } \\
\text { STEEL }\end{array}$ & \\
\hline Ingeniería e Industria & & AGRONOMY \\
\hline RESEARCH ARTICLE & $\begin{array}{l}\text { Carlos A. Montilla Montaña, Valentina Kallewaard Echeverri, Hernán A. } \\
\text { González Rojas }\end{array}$ & Wine industry \\
\hline
\end{tabular}
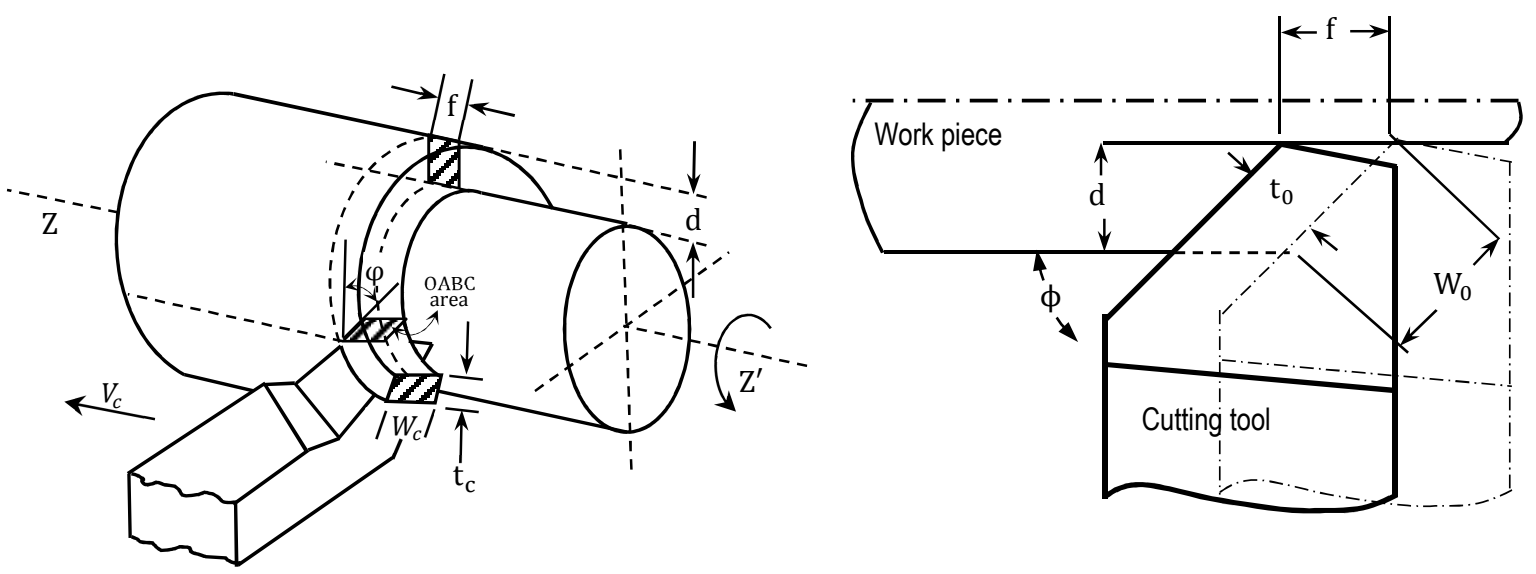

Fig. 2. Basic geometry of an oblique turning process

With the known rake angle, principal cutting-edge angle (Table 1) and chip dimensions, the shear angle is obtained using (2) and (3). Lastly, the shear plane area $A_{c}$ is obtained using (1). In Table 4 the intermediate values to calculate chip ratio $r$ can be consulted.

The electropulsing configurations during the metal-cutting experiments are presented in Table 2. (Remember that a pulsating current of $130 \mathrm{~A}$ is circulated through the tool and the piece).

\begin{tabular}{|c|c|c|c|c|c|}
\hline Condition & Frequency $(\mathrm{Hz})$ & $\begin{array}{l}\text { Pulse width } \\
\quad(\mu \mathrm{s})\end{array}$ & IRMS (A) & Shear plane area $\left(\mathrm{mm}^{2}\right)$ & $\begin{array}{c}\text { RMS Current density } \\
J_{s}\left(\mathrm{~A} / \mathrm{mm}^{2}\right)\end{array}$ \\
\hline C1 & \multirow{4}{*}{300} & \multirow{4}{*}{200} & \multirow{4}{*}{26,93} & 0,089 & 302,58 \\
\hline C3 & & & & 0,082 & 328,41 \\
\hline $\mathrm{C5}$ & & & & 0,192 & 140,26 \\
\hline C7 & & & & 0,169 & 159,35 \\
\hline
\end{tabular}

Table 2. Electropulsing parameters

\section{3.- TOOL LIFE MEASUREMENT}

The maximum flank wear $V_{B}$ defined in standard ANSI/ASME B94.55M [20] is obtained from the processing of images of the flank face, using a software that allows the direct measurement of flank wear. A dimensional metrology of the chips was carried out, to determine their average dimensions and verify the occurrence of changes in shape and size when applying electropulses.

For the optical measurement of flank wear $V_{B}$, a Nikkon L830 camera and the Drafsight 2015 software were used. Using a fixed and repeatable distance between the camera and the cutting edge of the tool, photographs were taken to the flank face once the machining process of each test specimen concluded. On the captured images, the upper and lower edges of the tool are projected, in order to locate the vanishing point, and then project a tangent. Figure 3 a) and b) show the wear on the incidence face on both tools and the lines generated by the software for the measurement of such wear. 


\begin{tabular}{|c|c|c|}
\hline Ingeniería e Industria & $\begin{array}{l}\text { EFFECT OF ELECTROPULSES ON THE MACHINABILITY OF A C45E } \\
\text { STEEL }\end{array}$ & AGRONOMY \\
\hline RESEARCH ARTICLE & $\begin{array}{l}\text { Carlos A. Montilla Montaña, Valentina Kallewaard Echeverri, Hernán A. } \\
\text { González Rojas }\end{array}$ & Wine industry \\
\hline
\end{tabular}
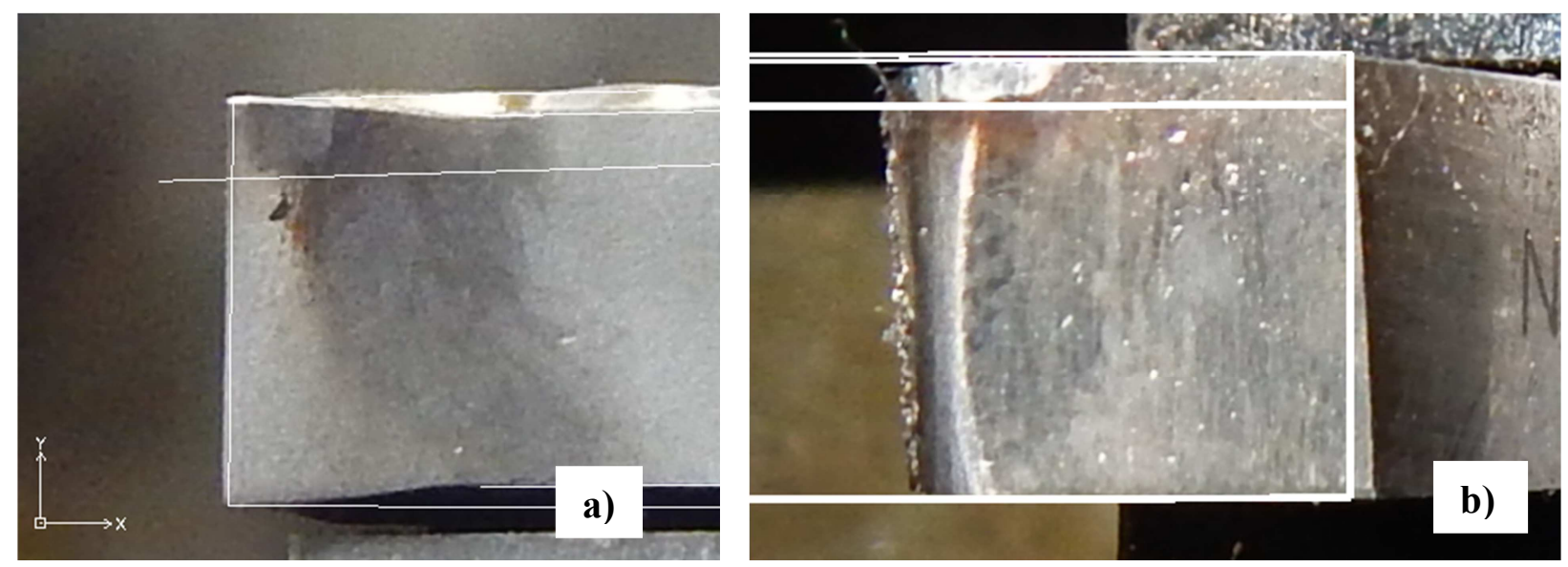

Fig. 3. V ${ }_{B}$ measurements. a) HM Tool b) HSS Tool

Surface roughness of the machined pieces was measured using a Mitutoyo SJ 201 surface roughness tester. The measurement of roughness $R_{a}$ was carried out according to standard ISO 1302-2002, perpendicular to the turning traces and with a cut-off of 2,5 mm. Five measurements of surface roughness were taken for each specimen on several zones and were processed in the Minitab software to evaluate dispersion and variance of each group. The analyses of variance ANOVA were performed with a confidence level of $95 \%$.

This indirect wear measurement technique is described by Seemuang et al. [21] and Jemielniak et al. [22], who show evident changes in surface roughness and mechanical vibrations when the tool wears, mainly since vibrations are a manifestation of variation in cutting forces, and the dimensional and geometric stability of the manufactured pieces are affected by those forces.

For each test condition, for every 3 specimens chip samples were taken and 7 of those samples were selected to measure its dimensions (width, thickness, outer length and inner radius). These were processed in the Minitab software, to evaluate dispersion of each group (ANOVA with a confidence level of $95 \%$ ).

For each of the test conditions mentioned on Table 1, the turning process is initiated removing $1 \mathrm{~mm}$ of depth to each specimen. Once a specimen has been turned it is taken out to measure roughness, and a photograph is taken to the flank face of the tool. The test continues with another unturned specimen. The test continues until the flank wear reaches a value of around $0,5 \mathrm{~mm}$.

It is convenient to mention that, on average, the execution of each of the aforementioned conditions implies about 40 hours of laboratory time, considering material acquisition, preparation of the test specimens, preparation and physical execution of the turning, measurements of chip width and thickness, roughness measurements, random selection of chips and photo shooting, software measurement of chip length and radiuses, processing of flank height on Draftsight, information processing on Mintab and Excel.

\section{3.- RESULTS AND DISCUSSION}

\section{1.- FLANK WEAR}

Figure 4 shows flank wear for both conventional and pulsed current assisted turning, when using a HSS cutting tool, for both spindle speed conditions. It can be seen that the evolution in time the flank wear experiences corresponds to the first two stages of the typical behavior described by Groover [11], Kalpakjian [23] and Bhtattacharyya [17], who describe three stages in the life behavior of a tool: break-in period, steady state wear region and failure region. Wear behavior $V_{B}$ in both test conditions obeys to linear models, with determination coefficients above 0.93 . Seemuang et al. [21] and Wang et al. [13], working on conventional turning processes, reported flank wear behavior similar in shape to

Publicaciones DYNA SL - c) Mazarredo n09 - 40 - 48009-BILBAO (SPAIN)
Tel +34 944237566 - www.revistadyna.com - email: dyna@revistadyna.com




$\left.\begin{array}{|c|c|c|}\text { EFFECT OF ELECTROPULSES ON THE MACHINABILITY OF A C45E } \\ \text { InTEEL }\end{array}\right]$

those shown on Figures 4 and 5. It was possible to observe that the type of machining process, conventional or assisted, doesn't significantly influence wear on the HSS cutting tool, for higher cutting speeds (Figure 4 (a)). In the case of lower cutting speeds, higher wear values are observed on the tool when the process is assisted. According to table 2 , current density for condition C5 is around $140 \mathrm{~A} / \mathrm{mm}^{2}$, whereas for condition C7 is around $160 \mathrm{~A} / \mathrm{mm}^{2}$, a subsequent study could determine if said difference has influence in the variation of wear found.

a)
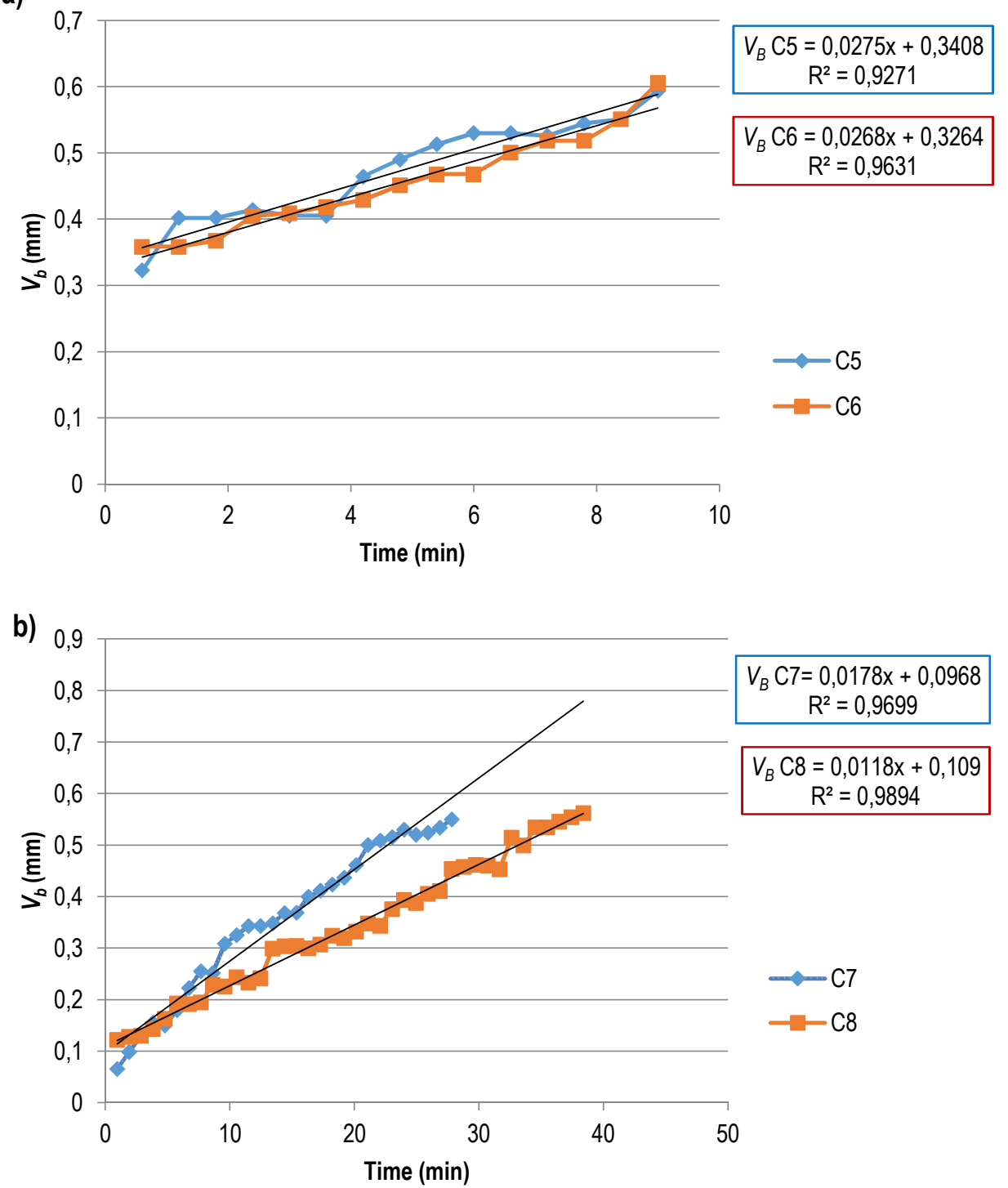

Fig. 4. Flank wear on HSS tool, a) Conditions C5 and C6, b) Conditions C7 and C8

Figure 5 shows flank wear obtained by machining with the HM tool, with and without electropulses assistance, for the two cutting speeds. The behavior that describes flank wear of HM tools for the highest cutting speed (conditions C1 and C2) corresponds to polynomic models, whereas for low cutting speeds (conditions C3 and C4) they are logarithmic. As it was the case with the HSS cutting tool, for the highest cutting speeds it is observed that the behavior of flank wear doesn't show significant differences when assisting the process with electropulses.

For this type of HM tool, assisted machining displays significant differences compared to conventional machining, at low cutting speeds. Figure 5(b) shows that a flank wear of $V_{B}=0,5 \mathrm{~mm}$ is reached in a very short time span, in the test condition without electropulses (C4), compared to the assisted one (C3). This phenomenon is probably due to the fact

Publicaciones DYNA SL - c) Mazarredo no69-40 - 48009-BILBAO (SPAIN)
Tel +34944 237 566-www.revistadyna.com - email: dyna@revistadyna.com




\begin{tabular}{|c|c|c|} 
EFFECT OF ELECTROPULSES ON THE MACHINABILITY OF A C45E \\
STEEL
\end{tabular} \mid $\begin{gathered}\text { AGRONOMY } \\
\text { Ingeniería e Industria } \\
\text { RESEARCH ARTICLE }\end{gathered}$

that current pulses reduce surface hardness and improve material conformability, according to reports by Sánchez et al. [8], consequently the effort required to remove the material will be less which translates into less tool wear.

For conditions $\mathrm{C} 1$ and $\mathrm{C} 3$ current densities are in the order of $300 \mathrm{~A} / \mathrm{mm}^{2}$ and $330 \mathrm{~A} / \mathrm{mm}^{2}$ (Table 2), respectively, which are higher than those applied during the turning with the HSS tool, a condition that can explain the differences in life of both tools. Some authors such as Roh et al. [24] and Liu et al. [25] talk of the existence of a threshold current density below which the electroplastic phenomenon doesn't manifest significantly, which is what could be happening with the HM and HSS tools, at the highest cutting speeds (C1 and C2, C5 and C6).
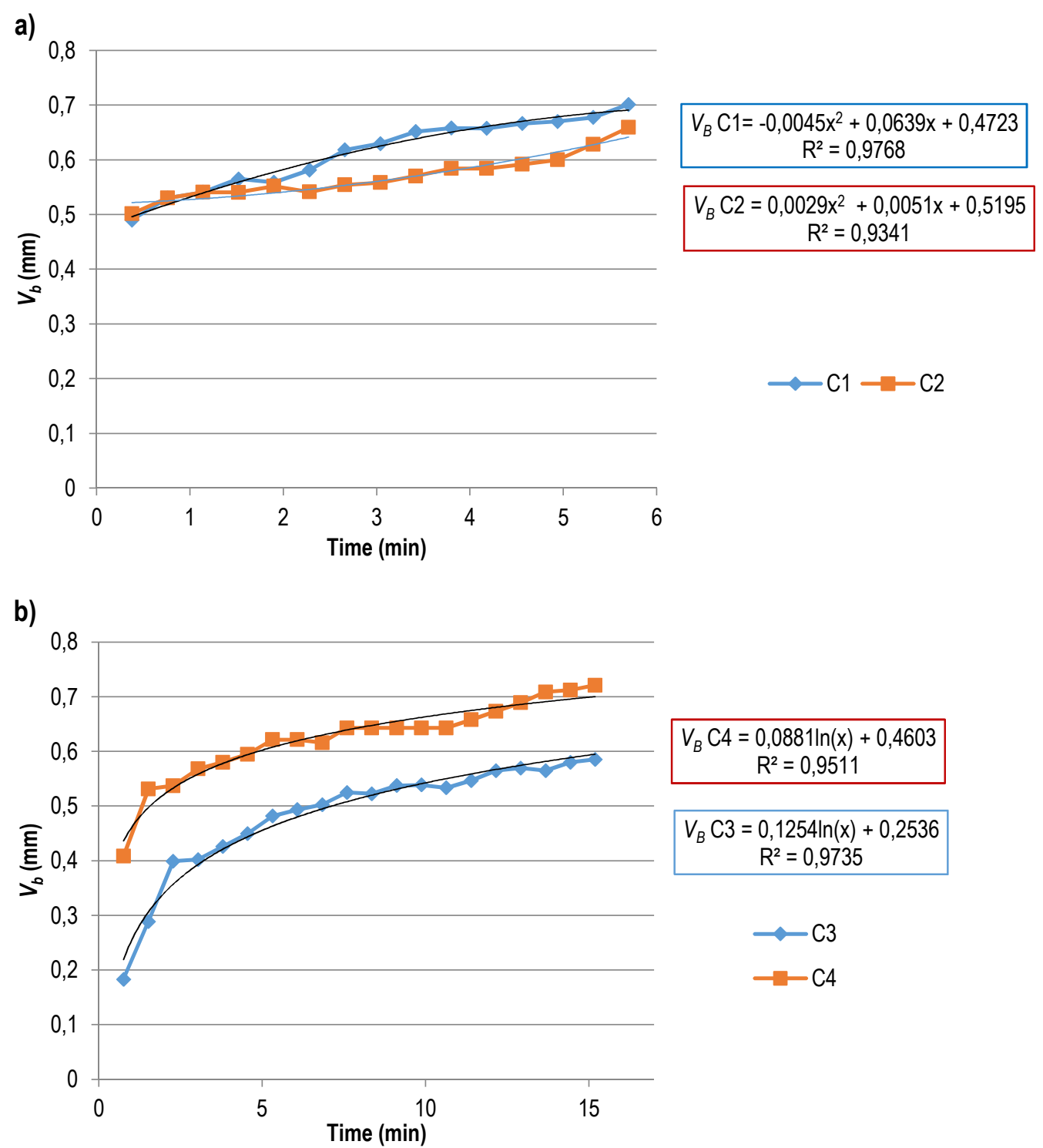

Fig. 5. Flank wear on HM tool, a) Conditions C1 and C2, b) Conditions C3 and C4

When machining with HM tools, at early test stages, flank wears, at the highest cutting speed (conditions C1 and C2) are higher than those of the lowest cutting speed (conditions C3 and C4). A similar situation is presented with the HSS cutting tools, higher flank wear at the highest cutting speed and early test stages (conditions C5 and C6), in comparison to those found at low cutting speed (conditions C7 and C8). This behavior is in line with what was reported by Groover [11], Kalpakjian [23] and Bhattacharyya [17].

Publicaciones DYNA SL - c) Mazarredo nº9 - 40 -- 48009-BILBAO (SPAIN)
Tel +34 $944237566-$ www.revistadyna.com - email: dyna@revistadyna.com




\begin{tabular}{|c|c|c|c|} 
EFFECT OF ELECTROPULSES ON THE MACHINABILITY OF A C45E \\
STEEL \\
Ingeniería e Industria \\
RESEARCH ARTICLE
\end{tabular}

\section{2.- SURFACE ROUGHNESS RESULTS}

In Table 3, for every test condition corresponding to electropulse assisted turning (C1, $\mathrm{C} 3$, $\mathrm{C} 5$ and $\mathrm{C} 7)$, the sample means of roughness indicate that the surface finish is better in relation to those obtained with conventional turning (C2, For the complete tests, an ANOVA with a p-value of 0,000 indicates that surface finish of turning with HSS tool, at the highest cutting speed, with and without EPT (C5 and C6), correspond to different populations. For the case of turning with HM tool, at lower cutting speed, with and without EPT (C3 and C4), an ANOVA with a p-value of 0,000 has also indicated they belong to different populations.

$\mathrm{R}_{\mathrm{a}}$ values with HM tool (C1 to $\left.\mathrm{C} 4\right)$, at early test stages don't show significant differences compared to values obtained for complete tests. On the contrary, $\mathrm{R}_{\mathrm{a}}$ values with HSS (C5 to C8), do show significant differences compared to full test values, becoming different populations for conditions $\mathrm{C} 7$ and $\mathrm{C} 8$ (p-value of 0,013 and 0,008 respectively).

\section{3.- CHIP DIMENSIONS}

In general, chip dimensions depend on cutting conditions, as exposed by Emel'yanov et al. [26] and Liu et al. [27]. In this section, the effect of the pulsed current on chip shape and dimensions is studied. Table 3 presents the estimation of chip thickness, widths and areas, for the different experiments.

\begin{tabular}{|c|c|c|c|c|c|c|c|c|}
\hline Condition & C1 & $\mathrm{C2}$ & $\mathrm{C3}$ & $\mathrm{C4}$ & $\mathrm{C5}$ & C6 & C7 & C8 \\
\hline $\begin{array}{c}\mathrm{Ra}_{\mathrm{a}}(\boldsymbol{\mu m}) \\
\text { Complete } \\
\text { test }\end{array}$ & $5,8 \pm 0,5$ & $6,0 \pm 0,4$ & $8,3 \pm 0,4$ & $9,5 \pm 0,8$ & $6,5 \pm 1,4$ & $8,4 \pm 0,9$ & $8,5 \pm 2,5$ & $8,9 \pm 1,6$ \\
\hline $\begin{array}{l}\mathrm{Ra}_{\mathrm{a}}(\mu \mathrm{m}) \\
\text { early test } \\
\text { stage }\end{array}$ & $5,7 \pm 0,2$ & $6,0 \pm 0,3$ & $8.2 \pm 0.1$ & $9,3 \pm 0,2$ & $5,8 \pm 0,4$ & $7.2 \pm 0,2$ & $5,5 \pm 0,7$ & $6,9 \pm 0,1$ \\
\hline $\begin{array}{l}\text { Uncut chip } \\
\text { thickness } t_{0} \\
\text { (mm) }\end{array}$ & \multicolumn{4}{|c|}{0,90} & \multicolumn{4}{|c|}{0,90} \\
\hline $\begin{array}{l}\text { Uncut chip } \\
\text { width } W_{0} \\
(\mathrm{~mm})\end{array}$ & \multicolumn{4}{|c|}{2,00} & \multicolumn{4}{|c|}{2,00} \\
\hline $\begin{array}{l}\text { Chip } \\
\text { thickness } t_{c} \\
(\mathrm{~mm})\end{array}$ & $\begin{array}{c}0,548 \pm \\
0,004\end{array}$ & $\begin{array}{c}0,565 \pm \\
0,014\end{array}$ & $\begin{array}{c}0,747 \pm \\
0,03\end{array}$ & $\begin{array}{c}0,763 \pm \\
0,077\end{array}$ & $\begin{array}{c}0,265 \pm \\
0,020\end{array}$ & $\begin{array}{c}0,207 \pm \\
0,012\end{array}$ & $\begin{array}{c}0,225 \pm \\
0,006\end{array}$ & $\begin{array}{c}0,230 \pm \\
0,012\end{array}$ \\
\hline $\begin{array}{l}\text { Chip width } \\
W_{c}(\mathrm{~mm})\end{array}$ & $\begin{array}{c}1,017 \pm \\
0,102\end{array}$ & $\begin{array}{c}0,948 \pm \\
0,078\end{array}$ & $\begin{array}{c}0,936 \pm \\
0,045\end{array}$ & $\begin{array}{c}0,938 \pm \\
0,045\end{array}$ & $\begin{array}{c}2,157 \pm \\
0,215\end{array}$ & $\begin{array}{c}1,777 \pm \\
0,127\end{array}$ & $\begin{array}{c}1,890 \pm \\
0,084\end{array}$ & $\begin{array}{c}1,652 \pm \\
0,263\end{array}$ \\
\hline Chip ratio $r$ & 0,164 & 0,159 & 0,120 & 0,118 & 0,340 & 0,435 & 0,400 & 0,391 \\
\hline $\begin{array}{c}\text { Chip area } \\
\left(\mathrm{mm}^{2}\right)\end{array}$ & 0,56 & 0,54 & 0,70 & 0,72 & 0,57 & 0,37 & 0,43 & 0,38 \\
\hline $\begin{array}{l}\text { Chip outer } \\
\text { length }(\mathrm{mm})\end{array}$ & $\begin{array}{c}10,623 \pm \\
0,764\end{array}$ & $\begin{array}{c}10,385 \pm \\
0,886\end{array}$ & $\begin{array}{c}11,007 \pm \\
1,976\end{array}$ & $\begin{array}{c}11,365 \pm \\
0,788\end{array}$ & $\begin{array}{c}77,480 \pm \\
8,99\end{array}$ & $\begin{array}{c}33,760 \pm \\
2,342\end{array}$ & $\begin{array}{c}104,200 \pm \\
20,400\end{array}$ & $\begin{array}{c}19,326 \pm \\
1,746\end{array}$ \\
\hline $\begin{array}{l}\text { Inner radius } \\
(\mathrm{mm})\end{array}$ & $\begin{array}{c}1,123 \pm \\
0,119\end{array}$ & $\begin{array}{c}1,135 \pm \\
0,073\end{array}$ & $\begin{array}{c}1,558 \pm \\
0,401\end{array}$ & $\begin{array}{c}1,442 \pm \\
0,128\end{array}$ & $\begin{array}{c}2,080 \pm \\
0,399\end{array}$ & $\begin{array}{c}1,430 \pm \\
0,175\end{array}$ & $\begin{array}{c}1,358 \pm \\
0,095\end{array}$ & $\begin{array}{c}1,228 \pm \\
0,071\end{array}$ \\
\hline
\end{tabular}

Table 3. Roughness, chip dimensions and chip ratio

The chips obtained in the turning process with HSS cutting tool with electropulses assistance (conditions C5 and C7) are continuous chip, type 5 conical helical, short, according to the standard ANSI/ASME B94.55M. On the other hand, chips obtained in the process of turning with HSS cutting tool without the electropulses assistance (conditions C6 and C8) are spiral chips, type 3 flat, according to the standard ANSI/ASME B94.55M. Using electropulses to assist the turning process with a HSS tool causes changes in chip morphology. 


\begin{tabular}{|l|c|}
\hline & $\begin{array}{c}\text { EFFECT OF ELECTROPULSES ON THE MACHINABILITY OF A C45E } \\
\text { STEEL }\end{array}$ \\
\hline $\begin{array}{c}\text { Ingeniería e Industria } \\
\text { RESEARCH ARTICLE }\end{array}$ & $\begin{array}{c}\text { AGRONOMY } \\
\text { Carlos A. Montilla Montaña, Valentina Kallewaard Echeverri, Hernán A. } \\
\text { González Rojas }\end{array}$ \\
\hline
\end{tabular}

From table 3 it can be seen that machining with a HSS tool at the highest cutting speeds (conditions C5 and C6) produces significant changes in chip thickness, areas and chip ratios. By assisting the process with electropulses, chip thickness increases (by 28\%), with that increases the shear strain and chip ratio decreases (by 78\%). An ANOVA with p-values of 0,000 indicate that chip thickness and width belong to different populations and that chip areas (thickness $t_{c}$ multiplied by width $W_{c}$ ) suffer a variation of $54 \%$. Since chip morphology changes by using electropulses to assist the turning with HSS tool, table 3 presents important changes in chip outer length and radius, in both the highest speed condition (C5 and C6) as well as in the lowest speed conditions (C7 and C8), that are confirmed with an ANOVA with p-values of 0,000 .

Hips obtained in the turning processes with HM tool are discontinuous type chip number 6 , arc chips loose. In table 3 (conditions $\mathrm{C} 1$ to $\mathrm{C} 4$ ) slight changes can be seen in the values of chip thickness, width, area, outer length, inner radius and chip ratio.

For the electropulses assisted test conditions (Table 2), the behavior of the flank wear is not traceable for all situations, it remains pending to explore other combinations of frequency and pulse width, with which all flank wears could be lower than with conventional machining.

As can be seen on table 3, chip ratio is lower when the machining process is assisted with electropulses, a situation also described on [28]; if chip thickness decreases, so does the shear stress [29], evidencing how the pulsed current produces an effect on chip shape and the material plasticity. The reasons behind this phenomenon are not completely understood and the Joule effect is one of the ideas most widely accepted as an answer to its genesis. Said effect is related to a localized increase in temperature in the primary deformation zone, a temperature that reduces yield tensile strength and ultimate tensile strength of the material. Nevertheless, the possibility to find explanations to the changes found on chip morphology and dimensions can be explored by conducting thermodynamic analysis studies of the electropulses assisted turning process, such as the one performed on classic turning process by Bhattacharyya [17], or analogously to the work developed by Sanchez et al [30].

\section{4.- CONCLUSIONS}

A life span study has been carried out on HM and HSS tools in a turning process assisted by current pulses, taking as a basis the cutting speed.

For higher cutting speed test conditions, there is no significant variation in flank wear behavior and thus in machinability. This occurred in both HM and HSS tools.

Flank wear on a HM tool assisted by pulses, at low cutting speeds, is less than the wear that the same tool suffers in a conventional turning process, a phenomenon that occurred throughout the test, indicating an improvement on machinability.

For HSS tools, it was found that flank wear was higher during the electropulse assisted process, regardless of the cutting speed.

Indirect assessment of the effect of tool wear shows a slight improvement in surface finish, by assisting the process with electropulses.

Experimental and statistical evidence shows that the electroplastic phenomenon in the turning process can change the type of chip. Significant changes in chip dimensions occur with the shear strain phenomenon.

The present work is a starting point for the study of improvements on machinability with the electropulse assisted turning process of metals. Further down the line, the intention is to study the behavior of the process with other widely industrially utilized materials (UNS G41400 or C20). The application of the Taguchi method will indicate the convenience of having a greater number of tests, combinations and variables.

\section{REFERENCES}




\begin{tabular}{|l|c|}
\hline $\begin{array}{c}\text { EFFECT OF ELECTROPULSES ON THE MACHINABILITY OF A C45E } \\
\text { STEEL }\end{array}$ \\
Ingeniería e Industria \\
\hline RESEARCH ARTICLE
\end{tabular}$\quad \begin{gathered}\text { AGRONOMY } \\
\text { Carlos A. Montilla Montaña, Valentina Kallewaard Echeverri, Hernán A. } \\
\text { González Rojas }\end{gathered}$

[1] Brecher C. Integrative Production Technology for High-Wage Countries. 1a edición. Springer-Verlag Berlin Heidelberg 435, 2012. 1096p. DOI 10.1007/978-3-642-21067-9_5. ISBN: 978-3-642-21066-2

[2] Ye Z, Zhang Z, Jin X, et al. "Study of hybrid additive manufacturing based on pulse laser wire depositing and milling". International Journal Advanced Manufacturing Technology. 2017. Vol. 88 p.2237-2248. Springer-Verlag London. DOI 10.1007/s00170-016-8894-8.

[3] Sajan K, Legesse F, Kulkarni P, et al. "Hybrid-layered manufacturing using tungsten inert gas cladding". Prog Addit Manuf. 2016. Vol. 1 p.79-91. Springer International Publishing Switzerland. DOI 10.1007/s40964-016-0005-8.

[4] Spitsyn VI, Troitskii OA. Deformación electroplástica de metales. 1ạ edición. Moscú, URSS: Editorial Nauka, 1985.

[5] Valoppi B, Sánchez A, Zhang Z, et al. "A hybrid mixed double-sided incremental forming method for forming Ti6Al4V alloy". CIRP Annals. 2016. Vol. 65 p.309-312. DOI: https://doi.org/10.1016/j.cirp.2016.04.135

[6] Hameed S, González H, Sánchez A, et al. "Electroplastic cutting influence on power consumption during drilling process". International Journal on Advanced Manufacturing Technology. 2016. Vol. 87 p.1835-1841. Springer-Verlag London. DOI: 10.1007/s00170-016-8562-z.

[7] Salandro W, Jones J, Bunget C, et al. Electrically Assisted Forming. 1a edición. Switzerland: Springer International Publishing, 2015. 355p. DOI 10.1007/978-3-319-08879-2. ISBN: 978-3-319-08878-5

[8] Sánchez A, González H, Montilla C, et al. "Manufacturing improves when turning process is assisted in situ by short time electropulsing". Journal of Materials Processing Technology. 2015. Vol. 222 p. 327-334. DOI: https://doi.org/10.1016/j.proeng.2015.12.526

[9] Sánchez A, González H, Montilla C, et al. "Turning process assisted in situ by short time current pulses". Procedia engineering. 2015. Vol. 132 p.507-512. DOI: https://doi.org/10.1016/j.proeng.2015.12.526

[10] Sánchez A, González H, Montilla C, et al. "Estudio de la variación de la rugosidad y dureza superficial en piezas torneadas, con la asistencia de electroplasticidad". En: Second International Conference on Advanced Mechatronics, Design, and Manufacturing Technology - AMDM 2014: Bogotá, Colombia.

[11] Groover M. Fundamentals of modern Manufacturing. Materials, processes and systems. 6a edición. USA: John Wiley \& Sons, Inc, 2015. ISBN: $978-1119128694$

[12] Zhang P, Liu Z. "Machinability investigations on turning of Cr-Ni-based stainless-steel cladding formed by laser cladding process". International Journal on Advanced Manufacturing Technology. 2016. Vol. 82 p.1707-1714. DOI: https://doi.org/10.1007/s00170-015-7474-7

[13] Wang X, Huang C, Zou B, et al. "A new method to evaluate the machinability of difficult-to-cut materials". International Journal on Advanced Manufacturing and Technology. 2014. Vol. 75 p.91-96. Springer-Verlag London. DOI: https://doi.org/10.1007/s00170-014-6126-7

[14] Geng H, Wu X, Wan H, et al. "Effects of copper content on the machinability and corrosion resistance of martensitic stainless steel". Journal of materials Science. 2008. Vol. 43 p.83-87. DOI: https://doi.org/10.1007/s10853-007-2084-x

[15] Siddhpura A, Paurobally R. "A review of flank wear prediction methods for tool condition monitoring in a turning process". International Journal on Advanced Manufacturing Technology. 2013. Vol. 65 p.371-393. DOI: https://doi.org/10.1007/s00170-012-4177-1

[16] Compañía general de aceros. SAE 1020 y SAE 1045. Aceros de ingeniería al carbono. 2007. Catálogo en línea disponible en: http://repository.unilibre.edu.co/bitstream/handle/10901/7826/VasquezTorresEdwinLibardo2013Anexos.pdf?sequence=2.

[17] Bhattacharyya A. Metal cutting: Theory and practice. New York, USA: New central Book Agency (P) Ltd, 1984. 657p. ISBN: 8173812284

[18] Hasan S. Thamizhmanii S. "Tool flank wear analyses on AISI 440 c martensitic stainless steel by turning". Int J Mater Form (2010) Vol. 2010. 3 Suppl 1:427 430 - @ Springer-Verlag France. DOI 10.1007/s12289-010-0798-9.

[19] Taylor, MR. F. W. ON the art of cutting of metals. Publicado por la American Society of Mechanical Engineers. 1906

[20] ANSI/ASME. Tool life testing with single-point turning tools. B94.55M-1985. ASME: New York, USA. 1985

[21] Seemuang N, McLeay T, Slatter T. "Using spindle noise to monitor tool wear in a turning process". International Journal on Advanced Manufacturing Technology. 2016. Vol. 86 p.2781-2790. DOI: https://doi.org/10.1007/s00170-015-8303-8

[22] Jemielniak K, Urbanski T, Kossakowska J, et al. "Tool condition monitoring based on numerous signal features". International Journal on Advanced Manufacturing Technology. 2012. Vol. 59 p.73-81. DOI: https://doi.org/10.1007/s00170-011-3504-2 


\begin{tabular}{|c|c|c|}
\hline Ingenieria e Industria & $\begin{array}{l}\text { EFFECT OF ELECTROPULSES ON THE MACHINABILITY OF A C45E } \\
\text { STEEL }\end{array}$ & AGRONOMY \\
\hline RESEARCH ARTICLE & $\begin{array}{l}\text { Carlos A. Montilla Montaña, Valentina Kallewaard Echeverri, Hernán A. } \\
\text { González Rojas }\end{array}$ & Wine industry \\
\hline
\end{tabular}

[23] Kalpakjian S, Schmid S. Manufactura, Ingeniería y Tecnología. 4a edición. México: Prentice Hall Inc, 2002. 1152p. ISBN: 9702601371

[24] Roh J, Seo J, Hong S, et al. "The mechanical behavior of 5052-H32 aluminum alloys under a pulsed electric current". International Journal of Plasticity. 2014. Vol. 58 p.84-99. DOI: https://doi.org/10.1016/j.jplas.2014.02.002

[25] Liu K, Dong X, Xie H, et al. "Effect of pulsed current on the deformation behavior of AZ31B magnesium alloy". Materials Science \& Engineering: A. 2015. Vol. 623 p.97-103. DOI: https://doi.org/10.1016/j.msea.2014.11.039

[26] Emel'yanov S, Yatsun E, Remnev A, et al. "Chip Curling in Metal Cutting”. Russian Engineering Research. 2011. Vol. 31, No. 7 p.679-683. DOI: $10.3103 / S 1068798 \times 11060086$

[27] Liu C, Wang G, Ren C, et al. Mechanistic modeling of oblique cutting considering fracture toughness and thermo-mechanical properties. International Journal on Advances Manufacturing and Technology. 2014. Vol. 74 p.1459-1468. DOI: https://doi.org/10.1007/s00170-014-6100-4

[28] Hameed S, González HA, Perat JI, Nápoles A, Sánchez AJ, Influence of the Regime of Electropulsing-Assisted Machining on the Plastic Deformation of the Layer Being Cut, Materials2018 Vol.11, 886 p2-10.

[29] Adam U.A, Noordin M.Y, Mohamed H.S.E; Hasan F, Influence of cutting conditions on chip formation when turning ASSAB DF-3 Hardened tool steel, Int. J. Mater. Mech. Manuf. 2013 Vol1 p76-79.

[30] Sánchez AJ, González HA, Celentano DJ, et al. "Thermomechanical Analysis of an Electrically Assisted Wire Drawing Process". Journal of Manufacturing Science and Engineering. 2017. Vol. 139. DOI: 10.1115/1.4037798

\section{ACKNOWLEDGEMENTS}

To Universidad Tecnológica de Pereira, for facilitating the economic resources, facilities and laboratories, for the physical execution of the present study, under research project $8-13-3$. To undergraduate students Diego Ramírez, Catalina Montilla, Alejandro Lema and Carlos E. Montilla, for their collaboration in the physical execution of the present project.

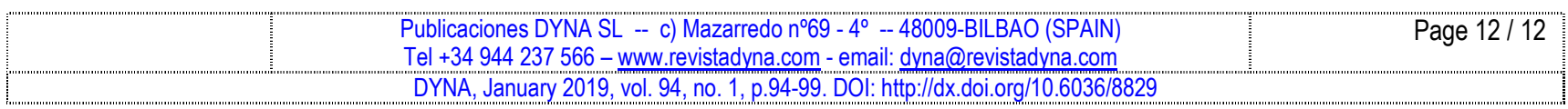

